\title{
Pulmonary Fibrosis caused by Asbestos Fibers in the Respiratory Airway
}

\author{
Ji-Woo Jung* and Eung-Sam Kim ${ }^{\dagger ; * *}$ \\ Department of Biological Sciences, Chonnam National University, Gwangju 61186, Korea
}

\begin{abstract}
Asbestos products had been widely used until 2007 in Korea since the 1930s. A total ban on their production and applications has been imposed because of the toxic effect of asbestos fibers on the human health. The inhaled asbestos fibers increase reactive oxygen species and inflammatory reactions in the respiratory airway including the alveolar sac, resulting in DNA damages and secretion of several inflammatory cytokines or chemokines. These paracrine communications promote the proliferation of fibroblasts and the synthesis of collagen fibers, thereby depositing them into the extracellular matrix at the interstitial space of alveoli. The fibrotic tissue hindered the gas exchange in the alveolus. This reviews describes not only the cytotoxic effects of asbestos fibers with different physical or chemical characteristics but also the interaction of cells that make up the respiratory airway to understand the molecular or cellular mechanisms of asbestos fiber-induced toxicity. In addition, we propose a pulmonary toxicity research technique based on the mini-lung that can mimic human respiratory system as an alternative to overcome the limitations of the conventional risk assessment of asbestos fibers.
\end{abstract}

Key Words: Asbestos fiber, Respiratory airway, Pulmonary inflammation, Pulmonary fibrosis, Mini-lung

\section{서 론}

석면(asbestos)은 화산활동에 의해 발생한 화성암의 일 종으로 규산염 섬유(silicate fiber)의 다발이 모여 형성된 광물이다. 석면 기반의 제품은 가격이 저렴하고 내구성이 우수할 뿐 아니라 단열 및 보온 기능이 뛰어나 과거 국내 에서 건축재, 마찰재, 방직재 형태로 다양하게 사용되었 다. 국내에서는 1930년대에 석면 광산이 개발되기 시작하 면서 본격적으로 석면 제품이 생산되기 시작했고, 2006년 까지 석면 제품의 수입량도 늘었던 만큼 지난 100 여년 동안 석면 사용량은 꾸준히 증가해왔다. 1970년대까지 가 옥의 지붕 슬레이트에 주로 사용되던 석면은 1990년대에 들어서면서 보온단열재, 천정판 등 다양한 건축자재로 활 용되면서 사용량의 증가뿐만 아니라 광범위하게 이용되었
다(Choi et al., 1988). 그러나 인체에 대한 석면의 위해성이 보고되기 시작하면서 1987년 세계보건기구(WHO)는 석면 을 1급 발암 물질(carcinogen)로 지정하였다. 이에 따라 다 수의 국가들이 석면 이용을 전면 금지하는 조치를 취하 기 시작했고, 우리나라에서도 2009년 석면과 석면 제품의 제조, 사용, 유통 및 수입이 전면 금지 되었다(Kim, 2009).

국내에서 보고된 석면관련 인체 피해 사례를 살펴보면, 국내 석면방직공장 근로자에게서 발병한 악성 중피종 (malignant mesothelioma)이 석면관련 산업재해로 1993년에 처음으로 인정된 후, 동일한 사업장에서 추가적으로 악성 중피종 5건, 석면폐(asbestosis) 7건이 발생한 것으로 조사 되었다(Gang, 2009). 이후 최근까지 석면과 관련된 국내 피해 사례는 꾸준히 증가하였다(Table 1). 10 여년 전까지 석면 제품의 사용이 지속되어 왔었고 석면 노출에 따른 직접적인 질병 및 합병증이 30 40년 이후에 나타나는 점

Received: August 18, 2021 / Revised: September 17, 2021 / Accepted: September 24, 2021

*Undergraduate student, ${ }^{* *}$ Professor.

${ }^{\dagger}$ Corresponding author: Eung-Sam Kim. Department of Biological Sciences, Research Center of Ecomimetics, Research Center of Next-Generation Sensors, Chonnam National University, 77 Yongbong-ro, Buk-gu, Gwangju 61186, Korea.

Tel: +82-62-530-3416, Fax:+82-62-530-3409, e-mail: eungsam.kim@chonnam.ac.kr

(C) The Korean Society for Biomedical Laboratory Sciences. All rights reserved.

(a) This is an Open Access article distributed under the terms of the Creative Commons Attribution Non-Commercial License (http://creativecommons.org/licenses/by-nc/3.0/) which permits unrestricted non-commercial use, distribution, and reproduction in any medium, provided the original work is properly cited. 
Table 1. Asbestos-related pulmonary diseases in Korea from 2014 to 2019 (source: Ko et al., 2020)

(unit: person)

\begin{tabular}{cccccc}
\hline \hline Year & Asbestosis & Malignant mesothelioma & Lung cancer & Diffuse pleural thickening & Total \\
\hline 2014 & 162 & 42 & 21 & 2 & 227 \\
2015 & 199 & 41 & 48 & - & 288 \\
2016 & 294 & 45 & 75 & 2 & 416 \\
2017 & 313 & 62 & 74 & - & 449 \\
2018 & 395 & 59 & 68 & - & 522 \\
2019 & 526 & 47 & 73 & - & 646 \\
\hline
\end{tabular}

을 고려하면 2030년대까지도 석면 피해 사례들은 꾸준히 보고될 것으로 전망되고 있다(Ko et al., 2020). 2009년 전 면 금지 조치가 내려진 이후에 기존에 생산되었던 석면 제품은 폐기되었고 석면 건축자재가 사용된 건물은 해체 과정에서 외부로 석면이 유출되지 않도록 엄격한 절차에 따라 해체되고 있다. 2021년 현재 환경부 석면관리종합정 보망의 통계자료에 의하면 국내에 22,079건의 석면건축물 이 여전히 존재하며 그 중에 공공건축물이나 어린이집도 상당수 포함되어 있어 석면 노출에 의한 피해 위험은 현 재 진행형인 실정이다.

석면에 의한 신체적 피해는 즉각적으로 발생하지 않기 때문에 석면의 특성과 석면에 노출된 호흡계의 변화를 잘 이해하지 못한다면 석면의 위해성을 간과하기 쉽다. 석면은 가느다란 석면섬유(asbestos fiber)의 다발로 구성된 광물이기 때문에 외부 요인에 의해 섬유 형태로 쉽게 분 리될 수 있다. 석면섬유는 $0.05 \sim 10 \mu \mathrm{m}$ 길이의 미세입자 형태로 공기 중에 부유할 수 있다. 사람의 호흡 과정을 통해 흡입된 석면섬유는 전도기도(conducting airway)를 구 성하는 기관, 기관지, 세기관지를 순차적으로 통과하여 호 흡기의 말단 부분인 호흡기도(respiratory airway)까지 도달 할 수 있다. 석면섬유가 호흡기도에 도달하여 축적되면 호흡기도를 구성하는 상피세포(epithelial cell)와 대식세포 (macrophage)에서 활성산소종(reactive oxygen species)을 발 생시키거나 조직에 물리적 손상을 일으킨다. 석면섬유 노출 초기에 호흡기도에 유발된 염증반응은 이후 석면섬 유가 대식세포에 의해 제거되지 않을 경우 만성적 염증 반응으로 진행된다(Macnab and Harington, 1967; Rosenthal et al., 1999). 이 때 분비되는 사이토카인(cytokine)들은 호 흡기도에 존재하는 섬유아세포(fibroblast)로부터 콜라겐 (collagen) 합성을 촉진시켜 세포외기질(extracellular matrix, $\mathrm{ECM})$ 을 두껍게 만든다. 그 결과 호흡기도에서 기체교환 (gas exchange)이 잘 일어나지 않는 상태인 미만성 흉막비 후(diffuse pleural thickening)가 여러 폐포에서 발견되는 석면폐로 악화될 수 있다. 호흡기도 가운데 폐포(alveolar $\mathrm{sac}$ )와 폐포관(alveolar duct)은 기체교환(gas exchange)이 가 장 활발하게 일어나는 부위이기 때문에 석면섬유로 인한 염증반응 및 섬유화는 향후 치명적인 결과를 초래할 수 있다.

전도기도의 섬모와 점액이 석면섬유가 호흡기도까지 도 달하는 것을 억제하는 역할을 하기 때문에 석면섬유가 호 흡기도에 도달할 확률은 상대적으로 낮은 편이다. 기존의 여러 연구들은 호흡기도 이전 부위에 축적된 석면섬유에 대한 피해 사례들에 초점을 맞추었다. 하지만 섬모와 점 액만으로는 석면섬유가 호흡기도에 도달하는 것을 완벽 하게 막을 수 없고 전도기도에 축적된 석면섬유가 파편 화되어 호흡기도까지 도달할 수 있어 이에 대한 명확한 이해가 필요한 실정이다. 이에 본 총설은 석면섬유가 기 체교환이 활발하게 일어나는 얇은 조직세포층으로 구성 된 호흡기도에 야기하는 위해성 기전을 분자·세포 생물 학적 관점에서 정리하고자 한다. 석면섬유에 의해 호흡기 도에서 일어나는 폐 섬유화(pulmonary fibrosis) 과정을 폐 포 대식세포(alveolar macrophage)의 관여 여부에 따른 두 가지 과정으로 나누어 기전을 설명할 것이다. 이를 통해, 석면섬유의 위해성과 호흡기도의 폐 섬유화증을 보다 명 확하게 이해하는데 도움을 주고자 한다. 또한 지금까지 그 중요성이 간과되어왔던 폐 조직의 기계적 자극 환경 에 대한 재고의 필요성과 최신 폐 조직 모사 실험 모델 을 소개함으로써 석면관련 폐 질환의 치료와 재활 방법 개발에 새로운 시각을 제시하고자 한다.

\section{본 론}

\section{석면섬유의 종류와 물리화학적 성질}

석면은 광물학적 분류에 따라 사문석(serpentine) 계열과 
Table 2. Comparison of serpentine and amphibole asbestos

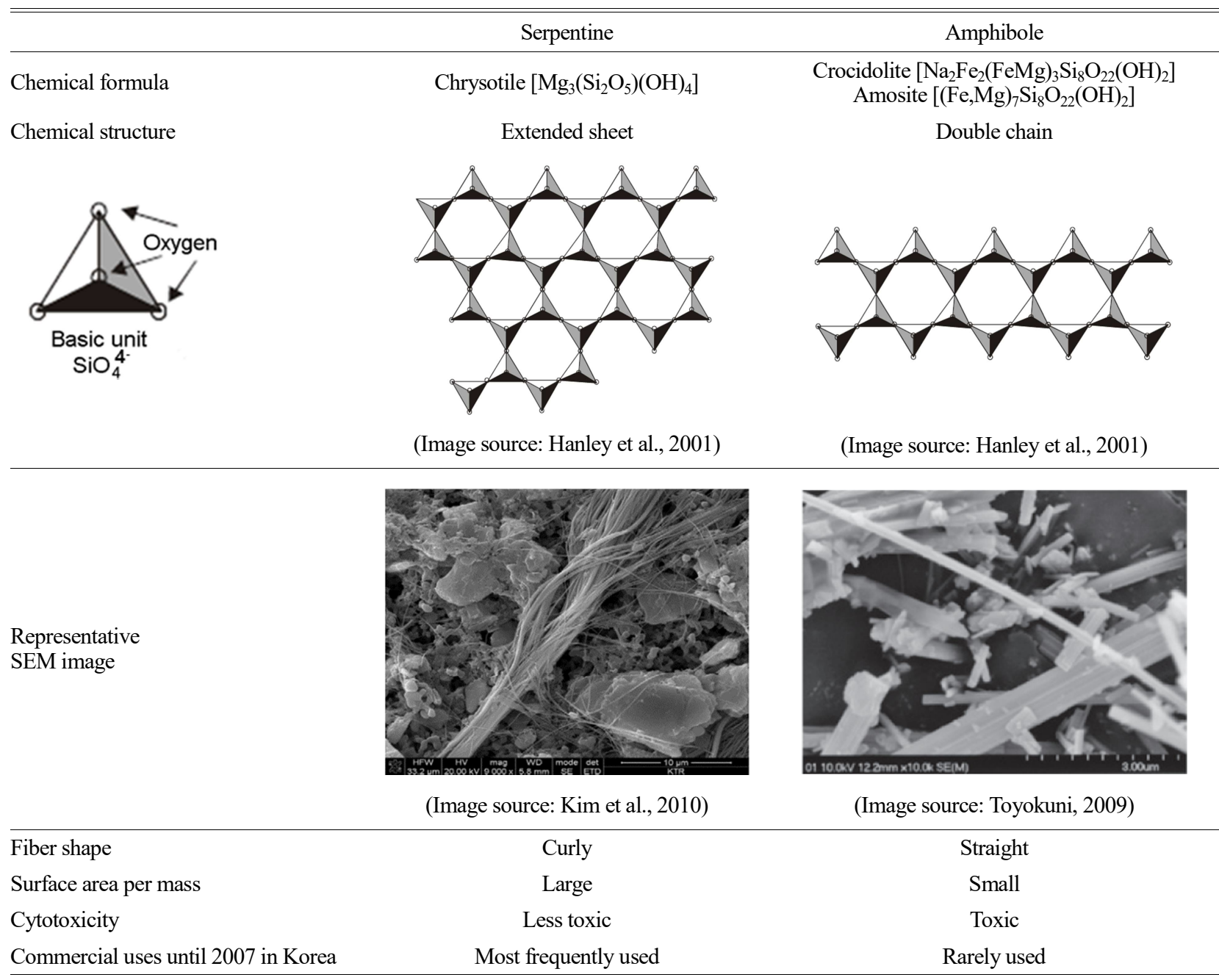

각섬석(amphibolite) 계열로 나눌 수 있다. 대표적으로 사 문석 계열에는 백석면(chrysotile)이 있고, 각섬석 계열에는 청석면(crocidolite)과 갈석면(amosite)이 있다(Table 2). 상업 적으로 사용되는 석면의 $95 \%$ 는 백석면이며, 청석면이 일 부 사용되지만 나머지 석면은 상품성이 낮아 거의 사용 되지 않는다. 백석면은 질량당 섬유다발 수가 많고(전체 표면적이 크다는 것을 의미함) 섬유구조의 배열이 불규칙 적이다(Solbes and Harper, 2018). 이에 비해 각섬석 계열의 섬유는 곧고 크기가 균일하다.

석면을 구성하는 섬유를 석면섬유라고 부른다. 섬유를 구성하는 단위체는 규산염(silicate, $\mathrm{SiO}_{4}{ }^{4}$ )이며 석면섬유는 $\mathrm{Si}-\mathrm{O}-\mathrm{Si}$ 결합으로 연결된 중합체이다. 각섬석 계열 석면은 규산염 중합체 사슬 두 가닥이 연결된 구조이며, 사문석 계열 석면은 규산염의 수평적 연결이 확장된 형태이지만,
원자간의 결합 위치가 조금씩 엇갈려 있기 때문에 뒤틀 린 평면구조를 가진다. 음전하를 띠는 규산염 섬유의 표 면에는 철 $\left(\mathrm{Fe}^{3+}\right)$ 혹은 마그네슘 $\left(\mathrm{Mg}^{2+}\right)$ 과 같은 금속 이온이 붙을 수 있다. 그 중에서 철 이온과 규산염 섬유로 구성된 석면섬유가 체내 유입이 되어 과도한 활성산소종이 만들 어져 세포독성이 나타나게 된다.

산소 환경에서 $\mathrm{Fe}^{3+}$ 는 높은 원자가 상태를 유지하기 때 문에 그 반응성이 크다. 따라서 $\mathrm{Fe}^{3+}$ 는 석면의 규산질 표 면과 쉽게 결합하는데 이는 마치 $\mathrm{Fe}^{3+}$ 가 환원되는 것과 유사한 효과를 나타낸다(Ghio et al., 1998). 그리고 이 표면 의 $\mathrm{Fe}^{3+}$ 가 실제로 환원되며, Haber-Weiss 반응과 Fenton 반응을 일으킨다(Fig. 1). 그 결과 폐포 세포 및 페포 면역 세포에서 $\cdot \mathrm{O}_{2}{ }^{-}$나 $\cdot \mathrm{OH}$ 와 같은 활성산소종이 만들어진다. 이 활성산소종은 세포 환경에서 iNOS (inducible nitric oxide 


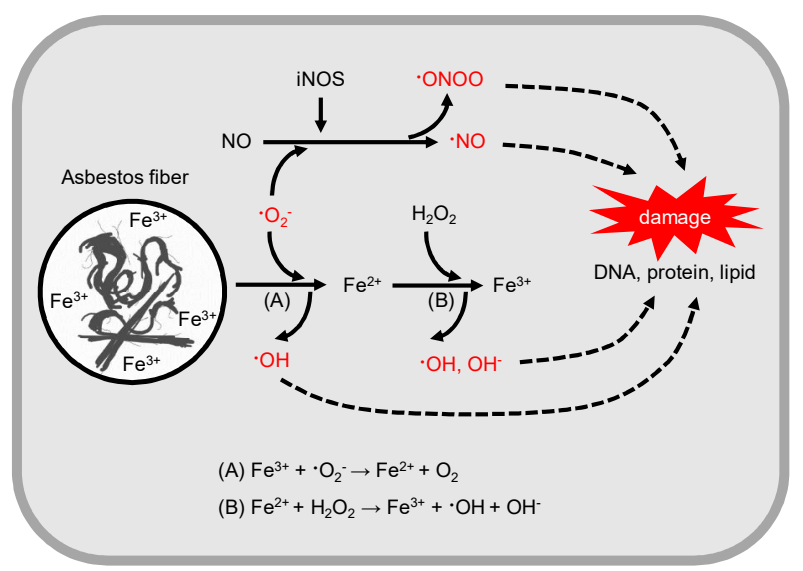

Fig. 1. Scheme of the biochemical process for generation of reactive oxygen or nitrogen species in alveolar or inflammatory cells exposed to asbestos fibers. (A) Harber-Weiss reaction. (B) Fenton reaction (Abbreviations: iNOS, inducible nitric oxide synthase).

synthase)와 반응하여 활성질소종(reactive nitrogen species) 을 만들기도 한다(Sun et al., 2010). 활성산소종과 활성질 소종은 DNA, 단백질, 지질에 무작위적 손상을 일으킬 수 있다(Fontecave et al., 1990). 이러한 라디칼 반응은 종결 이 전까지 계속 주변으로 전파되며 반응이 진행되는 특성이 있으며 세포와 석면섬유가 접촉하는 면적에 비례한다. 각 섬석 계열 석면섬유보다 질량당 표면적이 큰 사문석 계 열 석면섬유는 활성산소종 발생 능력이 크다는 것이 보 고되었다(Ghio et al., 1998). 석면섬유의 질량당 표면적이 크면 세포와 접촉면도 커지면서 활성산소종을 발생시킬 확률이 높아질 수 있지만 석면섬유의 세포독성에 있어 활성산소종의 발생 이외에 다른 요인들이 관여한다.

\section{폐의 구조와 호흡기도를 구성하는 세포들}

인간의 폐는 4주차의 태아에서 폐아(lung bud)에서 분지 (branching)되어 1세대 주기관지를 형성한다(Kwan et al., 2010). 이후 23세대까지 분지가 일어나 완전한 폐 구조를 형성하는데 기도의 분지된 세대에 따라 해부학적 분류 가 가능하다. 분지가 일어난 분기점은 기도분기점(airway bifurcation), 5 16세대를 말단세기관지(terminal bronchiole), 17 19세대를 호흡세기관지(respiratory bronchiole), 20 22 세대를 폐포관(alveolar duct), 23세대를 폐포낭(alveolar sac) 이라고 명명한다. 말단세기관지까지 기체교환에 관여하지 않는 부위는 전도기도이며, 17 세대 아래의 기관지는 기체 교환에 직접 관여하기 때문에 호흡기도로 분류한다(Fig. 2).

상대적으로 조직세포층이 얇은 호흡기도와 폐포는 폐

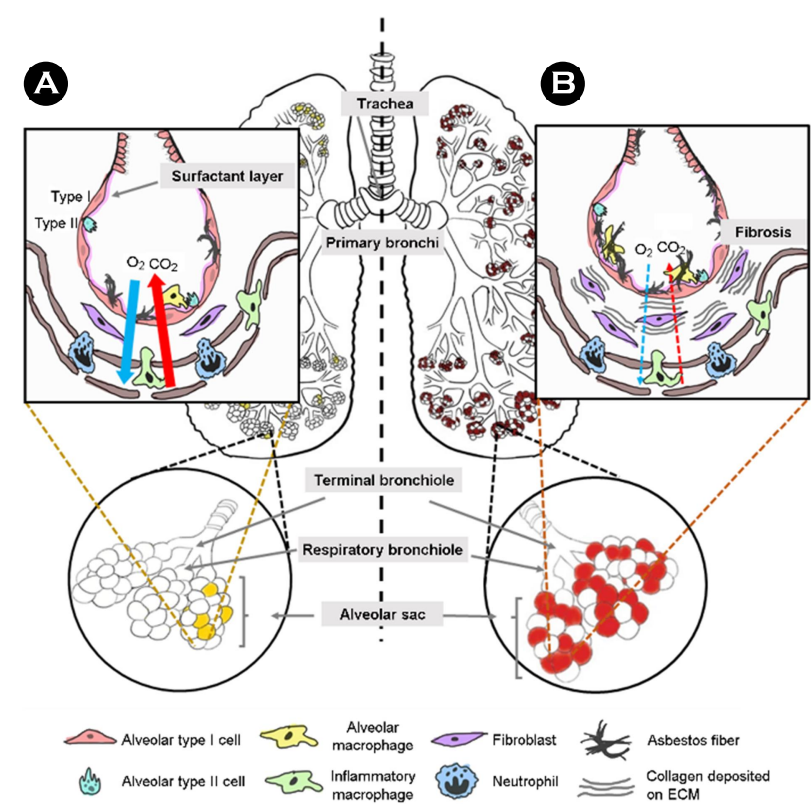

Fig. 2. Pulmonary fibrosis associated with the exposure time or amount of asbestos fibers. The normal, inflammatory, and fibrotic alveoli are colored in white, yellow, and red, respectively. (A) Early phase of alveolar fibrosis by asbestos fibers. (B) Pulmonary fibrosis by sustained exposure to asbestos fibers.

포 대식세포, 섬유아세포, 상피세포(epithelial cell)로 구성 되어 있다(Fig. 2). 폐포 대식세포는 주로 폐포에 상주하며 병원균이나 석면섬유와 같은 외부 물질을 포식한다. 섬유 아세포는 호흡기도와 폐포의 상피세포와 모세혈관 사이에 존재하며 콜라겐 섬유를 합성하는 역할을 한다. 상피세포 들 중 특히 폐포에 있는 상피세포는 I형 폐포 상피세포 (alveolar type I epithelial cell)와 II형 폐포 상피세포(alveolar type II epithelial cell)로 나눌 수 있는데, I형 폐포 상피세포 는 폐포 면적의 대부분을 차지하고 있으며 II형 폐포 상 피세포는 폐포 세포 수의 대부분을 차지한다(Fig. 2). II형 폐포 상피세포는 I형 폐포 상피세포로 분화하거나 I형 폐 포 상피세포 표면을 계면활성제 층(surfactant layer)으로 도 포한다(Fig. 2). 폐포 상피세포는 호흡으로 인한 기계적 자 극, 즉, 팽창과 이완을 받는 세포인데 이 계면활성제층은 비정상적인 폐포의 변형 및 접힘을 방지하는 역할을 한 다(Yang et al., 2020).

\section{석면섬유의 흡입 및 축적과 폐 섬유화의 진행 과정}

석면섬유의 흡입으로 인한 폐 조직 내 축적 과정을 추 적하기 위해 모델 동물에 기반한 연구들이 진행되어왔다. 이를 통해 석면섬유의 위해성을 결정하는 데 있어 석면 
섬유의 길이가 중요한 요인인 것을 확인하였다(Barlow et al., 2017). 길이가 긴 석면섬유는 폐포 대식세포에 의한 포식이 잘 일어나지 않아 제거되지 않고 폐포 내 간질 조직(interstitial space)에 장기간 축적된다는 결과가 보고되 었다. 또한 길이가 긴 석면섬유가 부러지면서 세기관지를 지나 호흡기도에 도달함으로써 석면섬유의 길이가 길수 록 호흡기도에 대한 위해성이 증가한다는 결과도 알려졌 다. 하지만 실제로 석면 환경에 노출된 사람의 경우에는 여러 길이의 석면섬유가 혼합된 형태로 흡입되지만 지금 까지 진행되었던 대부분의 동물 실험들은 특정 길이의 석면섬유만을 사용한 실험이라는 점에 있어 실제로 야기 되는 석면의 위해성을 정확하게 이해하는데 한계가 있다.

석면섬유가 비강을 통해 흡입되면 $10 \mu \mathrm{m}$ 이상 길이의 섬유들은 전도기도를 지나기 전 점액층에 있는 섬모의 운동에 의해 대부분 제거된다(Kwan et al., 2010). 그러나 길이가 $2 \mu \mathrm{m}$ 이하의 미립자 형태로 흡입되거나 석면섬유 를 포함한 분진에 지속적으로 노출되면 석면섬유는 호흡 기도의 상피세포층에 부착되거나 축적된 후 염증반응을 수반하며 상피세포를 관통한다(IARC Working Group, 2012). 이 때 축적되는 정도는 섬유의 직경과 비례하여 증가하 고 주로 축적되는 위치는 석면섬유의 구조적 차이 때문 에 사문석 계열은 기도분기점에, 각섬석 계열은 폐포관에 주로 축적된다. 축적된 석면은 기체의 이동경로를 방해하 기도 하는데 이 방해 능력은 섬유의 길이와 비례하여 증 가한다.

폐 섬유화는 석면섬유에 노출된 호흡기도 내 간질 조 직층에서 일어난다. 노출 초기에는 일부 호흡기도에서만 섬유화가 일어나지만, 지속적으로 석면섬유에 노출되면 일부 석면섬유가 상피세포를 관통하거나 림프관을 주변 조직으로 이동하여 폐 대부분 영역에서 섬유화가 진행된 다. 최종적으로 기체교환 기능이 현저하게 떨어지는 석면 폐로 이어진다(Fig. 2).

\section{석면섬유가 호흡기도 조직에 미치는 세포독성}

석면섬유가 호흡기도를 구성하는 세포에 대한 세포독 성을 야기하는 경로는 크게 두 가지로 나뉘어진다. 이 두 경로는 공통적으로 활성산소종과 사이토카인들이 관여하 여 염증반응, 세포자살(apoptosis)을 일으키고 최종적으로 섬유아세포의 콜라겐 합성을 촉진시켜 세포외기질을 두 껍게 만드는 섬유화로 이어진다. 두 경로의 가장 큰 차이 는 섬유화 과정에서 폐포 대식세포의 직접적인 관여의 여 부이다.
첫 번째 경로에서는 폐포 대식세포가 관여하지 않은 상태에서 석면섬유가 호흡기도의 상피세포를 직접 손상 시켜 활성산소종과 사이토카인이 발생한다. 두 번째 경로 에서는 석면섬유 제거에 실패한 폐포 대식세포가 사멸하 면서 활성산소종과 사이토카인이 방출된다. 사이토카인은 조직이 물리적 또는 병리학적 손상(예, 세균에 의한 감염) 을 입었을 때 면역세포에서 분비되는 세포 사이의 신호 전달 물질이고 면역반응을 진행하는데 중요한 역할을 한 다(Fajgenbaum and June, 2020).

석면섬유는 이 두 경로를 통하여 최종적으로는 폐 섬 유화증을 유발한다. 폐 섬유화는 섬유아세포에서 과도하 게 분비된 콜라겐 단백질들이 세포외기질에 축적되면서 세포외기질이 섬유단백질로 인해 두꺼워지는 현상이다. 호흡기도는 폐포를 둘러싼 모세혈관과 직접적으로 기체 교환을 하는 중요한 역할을 한다. 용이한 기체교환을 위 해 얇은 세포층으로 되어 있는 폐포 내 간질 조직이 섬 유화로 인해 두꺼워지면 기체 확산속도가 현격하게 줄어 든다. 이로 인하여 원활한 기체교환이 일어나지 못해 호 흡 장애가 나타난다.

석면섬유의 종류, 길이, 축적 및 제거 속도가 석면섬유 에 의한 세포독성을 결정하는 요인이다. 특히 석면섬유의 종류를 제외한 나머지 요인들은 서로 밀접하게 연관되어 있다(Seaton, 1989). 즉, 석면섬유의 길이가 길면 전도기도 에 존재하는 섬모와 점액에 의해 외부로 배출될 수 있어 호흡기도에 도달할 확률이 낮아진다. 하지만 이러한 석면 섬유가 호흡기도에 도달할 경우, 대식세포가 $10 \mu \mathrm{m}$ 이상 길이의 석면섬유를 쉽게 포식할 수 없어 장기간 축적될 수 있다. 반면에 석면섬유의 길이가 짧으면 호흡기도에 쉽게 도달할 수 있지만 대식세포에 의한 제거도 빠르게 일어난다(Koerten et al., 1990). 석면섬유의 종류 측면에서 는 일반적으로 청석면, 갈석면, 백석면 순으로 세포독성 이 나타난다. 각섬석 계열 석면섬유는 사문석 계열 석면 섬유에 비해 호흡기도에 더 잘 축적된다. 또한 대식세포 가 사문석 계열 석면섬유를 더 잘 제거할 수 있어 각섬 석계 석면섬유가 훨씬 더 유해하다.

\section{폐포 대식세포가 관여하지 않는 폐 섬유화 과정}

폐포 조직에 도달한 석면섬유는 조직 세포막의 일부 수용체를 활성시키거나 석면섬유 유래의 철 이온의 환원 과정을 통해 대식세포의 직접적인 관여 없이도 폐 섬유 화를 초래할 수 있다(Fig. 3). 석면섬유는 폐포 상피세포 나 섬유아세포의 EGFR (epidermal growth factor receptor)를 


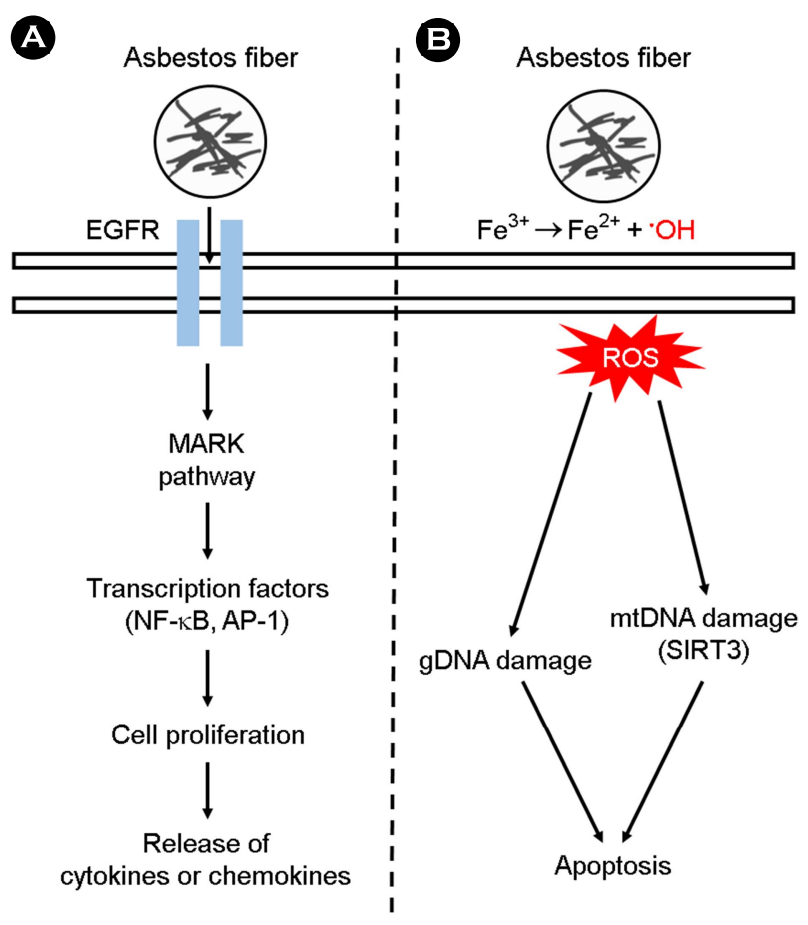

Fig. 3. Signaling cascades of the macrophage-independent fibrosis in the alveolar tissue. (A) The activation of the EGFR downstream by asbestos fibers leads to the increase in the level of cytokines or chemokines for the full-scale inflammation. (B) ROS generated in alveolar cells or fibroblasts by asbestos fibers damage gDNA and $\mathrm{mtDNA}$, resulting in their apoptotic cell death (Abbreviations: EGFR, epidermal growth factor receptor; MAPK, mitogen-activated protein kinase; NF- $\mathrm{KB}$, nuclear factor-kappa $\mathrm{B}$; AP-1, activator protein-1; mtDNA, mitochondrial DNA; ROS, reactive oxygen species; TNF- $\alpha$, tumor necrosis factor- $\alpha$; IL, interleukin; MIP, macrophage inflammatory protein).

활성화시켜 MAPK (mitogen-activated protein kinase) 경로 를 통해 NF- $\mathrm{BB}$ (nuclear factor-kappa B)와 AP-1 (activator protein-1)과 같은 전사인자(transcription factor)들의 발현을 촉진한다(Shukla et al., 2003a). 이들 전사인자는 면역세포 들의 증식을 증가시킴으로써, TNF- $\alpha$ (tumor necrosis factor$\alpha$ ), IL-1 $\beta$ (interlukin-1 $\beta$ ), IL-6와 같은 염증반응을 일으키는 주요 사이토카인들과 MIP-1 $\alpha$ (macrophage inflammatory protein-1 $\alpha$ ), MIP-3, IL-8과 같은 케모카인(chemokine)의 분 비를 증대시킨다(Rappolee et al., 1988). 케모카인은 다른 면역세포들을 병변 주변으로 불러들이고 활성화시켜 염 증반응을 증폭시키는데 대표적으로 IL-8은 호중성 백혈 구(neutrophil)를 활성화하고 이들을 염증 부위로 모여들게 한다.

석면섬유의 구조적 특징 때문에 $\mathrm{Fe}^{3+}$ 의 환원을 통한 Haber-Weiss 반응과 Fenton 반응이 일어나 활성산소종이 발
생하는데, 이 활성산소종은 핵 DNA (genomic DNA, gDNA) 와 미토콘드리아 DNA (mitochondrial DNA, mtDNA)에 심각한 손상을 주어 결국 세포자살과 폐 섬유화로 진행 될 수 있다(Shukla et al., 2003b). 또한 석면섬유는 히스톤 (histone)과 높은 친화도를 갖고 있어 석면섬유가 핵 안으 로 유입되면 $\mathrm{gDNA}$ 에 손상을 가한다는 연구 결과가 보고 되었다(Jiang et al., 2008).

미토콘드리아에 sirtuin (SIRT) 계열 중 하나인 SIRT3 유 전자가 있다. SIRT3은 미토콘드리아 내에서 중요한 기능 을 하는 여러 단백질들을 탈아세틸화 시킴으로써 활성화 하여 세포의 물질대사를 촉진시킨다(Jablonski et al., 2017). 특히 SIRT3는 MnSOD (manganese superoxide dismutase)의 K68 탈아세틸화와 mtOGG1 (oxoguanine DNA glycosylase1) $\mathrm{K} 338 / \mathrm{K} 441$ 탈아세틸화에 관여하는데 이들은 활성산소종 에 대한 손상을 완화시키는 기능을 하는 유전자들이다. 이 때 활성산소종에 의해 SIRT3와 같은 중요한 기능을 하는 유전자가 손상되고 활성산소종 제거 기전에 관여하 는 여러 유전자들이 차례로 활성을 잃으면 활성산소종에 의한 피해가 극대화된다(Huang et al., 2012). 또한 석면섬유 로 발생한 활성산소에 의한 미토콘드리아 유전자의 손상 은 미토콘드리아의 핵심 기능인 세포호흡을 저해할 수 있어 결국 상피세포와 대식세포의 에너지 고갈에 의한 사 멸을 유도할 수 있다.

\section{폐포 대식세포가 관여하는 폐 섬유화 과정}

폐포 대식세포가 체내에 들어온 석면섬유를 접하게 되 면 식균작용을 통해 석면섬유를 세포 내부로 가져온다. 이 때 내포된 섬유의 길이는 대식세포의 생존에 결정적 인 영향을 미친다. 길이가 긴 섬유는 포식 이후 폐포 대 식세포의 세포질에 완전히 내포되지 못하기 때문에 폐포 대식세포의 세포막을 파괴시켜 세포소기관의 누출을 유 도할 수 있다(Schinwald and Donaldson, 2012). 하지만 이 는 폐포 대식세포에 대해 석면섬유가 미치는 세포독성 의 주요한 요인은 아니다. 석면섬유는 $\beta$-tubulin, vimentin, lamin $\mathrm{A} / \mathrm{C}$, actin 등의 세포골격과 세포운동에 관여하는 단 백질들과 결합할 수 있다. 세포질분열 과정에서 운동단백 질에 부착된 석면섬유는 폐포 대식세포의 세포질분열을 방해한다. 이 때 석면섬유의 길이와 내재된 방향이 폐포 대식세포에 대한 세포독성을 결정하는 중요한 요인이 된 다(Ishida et al., 2019). 길이가 짧은 석면섬유나 세포분열 방향에 대해 수직으로 내재된 석면섬유는 세포질분열에 큰 문제를 일으키지 않지만 길이가 긴(10 $\mu \mathrm{m}$ 이상의) 석 


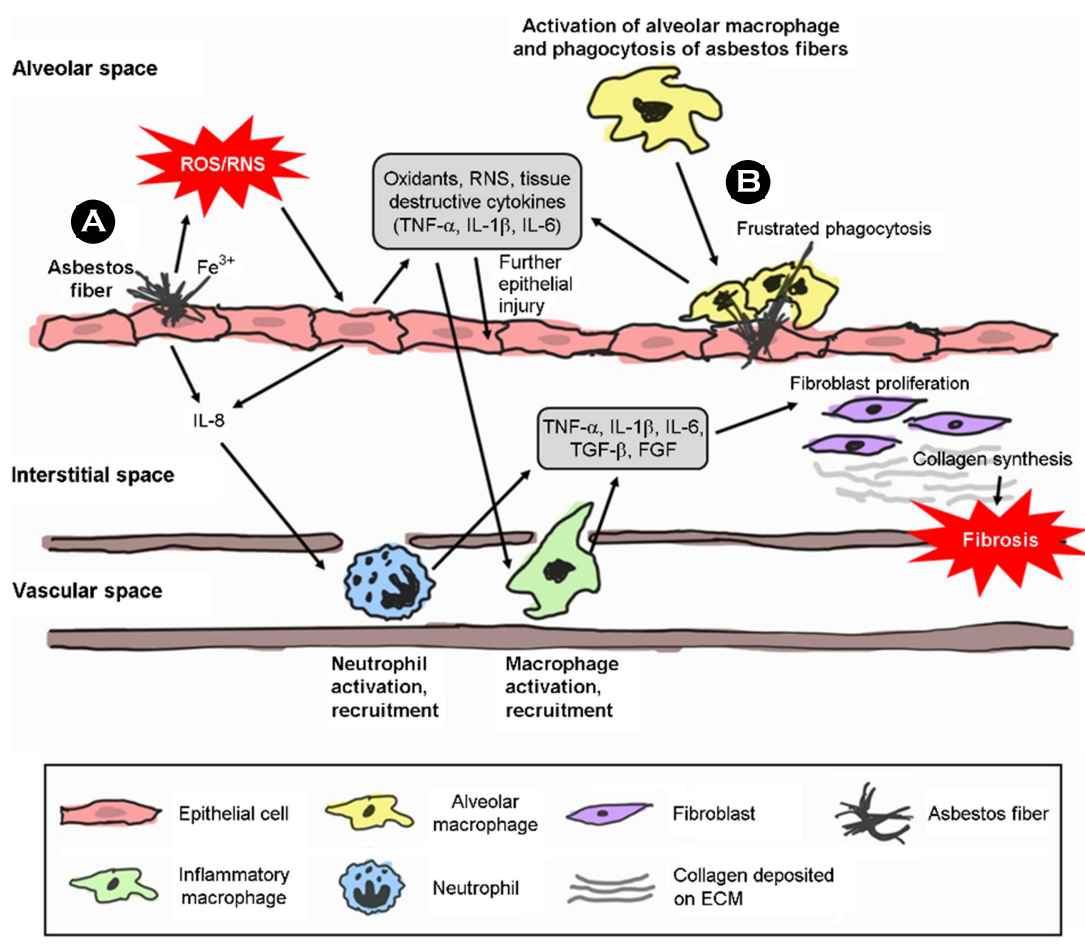

Fig. 4. Two pathways to the pulmonary fibrosis in the alveolus. (A) The reactive oxygen or nitrogen species that can be produced by asbestos-exposed epithelial cells trigger the cascade of the fibrosis with no involvement of macrophages. (B) Macrophages that fail to uptake the asbestos fibers release cytokines and ROS during their cell death. ROS and cytokines released from the two pathways damage the alveolar cells while these molecule activate neutrophils and macrophages to recruit them to the damaged sites. Some cytokines and growth factors stimulate the fibroblast in the interstitial space to enhance the synthesis of collagen fibers, resulting in abnormally thickening the extracellular matrix (Abbreviations: ROS, reactive oxygen species; TNF- $\alpha$.tumor necrosis factor- $\alpha$; IL, interleukin; TGF- $\beta$, transforming growth factor$\alpha$; FGF, fibroblast growth factor)

면섬유가 세포질분열 방향과 평행하게 내재된다면 세포 질분열을 방해하여 염색체의 안정성을 저해하거나 이수 성 돌연변이를 형성할 수 있다.

대식세포는 폐 조직의 조직손상이 일어났을 때 염증반 응을 조절하여 조직의 수선, 세포 증식, 세포 재생에 관 련하고 있다(Wynn et al., 2013). 폐포 대식세포가 손상되면 염증반응이 악화될 수 있다. 실제로 상처가 발생한 후 대 식세포 수의 감소는 염증반응을 급격하게 감소시키는 것 으로 확인되었다(Duffield et al., 2005). 염증반응은 손상된 조직의 죽어가는 세포들에 의해 유도한다. 이러한 염증반 응이 정상적으로 진행되면 손상된 조직은 회복되지만, 만 일 이 과정이 방해를 받거나 지체된다면 섬유화를 일으 키거나 주변 정상세포 및 조직까지 손상시켜 조직의 괴 사가 진행될 수 있다(Wynn and Ramalingam, 2012).

폐포 대식세포가 관여하지 않는 폐 섬유화 과정과 마 찬가지로 석면섬유에 의해 손상된 조직의 세포에 의해 각종 사이토카인과 케모카인 들이 분비된다(Fig. 4B). 그 결과 골수에서 대식세포의 전구체인 단핵구 형성이 유도 되고 모세혈관을 통해 석면섬유에 노출된 부위로 대식세 포들이 모여들게 된다(Wynn and Vannella, 2016). 그 후 활 성화된 대식세포는 사이토카인을 분비하는데, 이들 사이 토카인들은 손상된 조직의 복구를 위해 심한 손상이 일
어난 세포는 자살하도록 명령하고 새로운 세포의 증식을 촉진하며, 다른 면역세포들을 손상 부위로 불러모은다 (Rappolee et al., 1988). 그리고 섬유아세포를 자극하여 섬 유화를 통해 손상이 일어난 부위를 막는다. 하지만 이 반 응들이 비정상적으로 장기간 지속된다면 자살세포들이 증가하고 그것으로 인해 폐포의 비정상적인 섬유화가 일 어날 수 있다. 세포 증식과 분화 과정 또한 과도하게 진 행된다면 폐포 조직의 괴사가 일어나거나 종양이 발생할 수 있다.

\section{향후 연구 방향}

석면섬유의 위해성과 관련한 지금까지의 여러 연구들 은 폐 조직의 특성과 세포 환경의 특성을 고려하지 않은 한계점을 가진다. 석면섬유의 호흡계에 대한 보다 정확한 위해성 평가를 위해 폐의 생리학적 특성이 반영된 실험 모델 구축이 필요한 실정이다. 폐포는 호흡에 따른 지속 적인 기계적 신장과 이완을 반복하는 조직으로, 폐 조직 의 세포들은 이러한 기계적 자극 환경하에 놓여있다. 세 포 모델 연구에서 기계적 자극의 존재 여부에 따라 세포 의 반응성이 달라지는 것이 보고되고 있다. 폐포를 구성 하는 세포들이 물리화학적 손상을 받은 이후에 기계적 자극이 주어졌을 때 $\mathrm{DNA}$ 손상 및 염증반응이 가속화되 


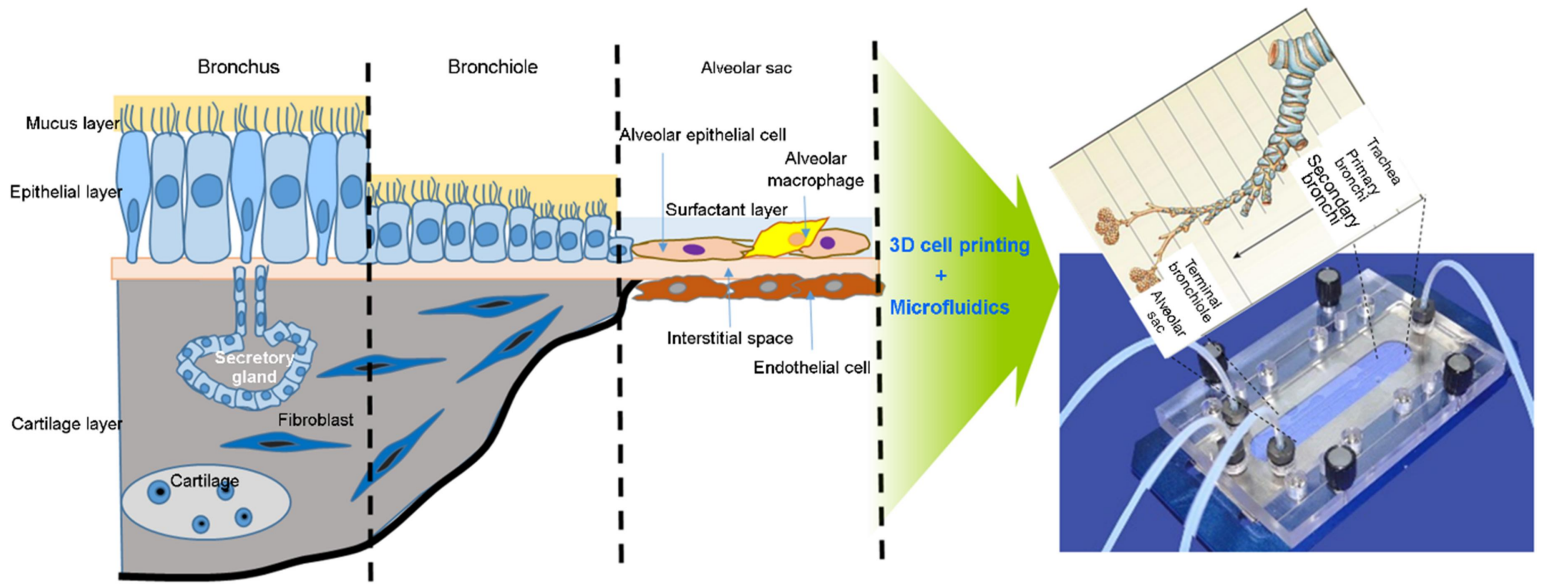

Fig. 5. Schematic illustration of the mini-lung to be reconstructed by combining 3D cell printing and microfluidic approaches for mimicking the anatomical hierarchy of the human lung with the trachea, bronchi, bronchiole, and alveoli. The mini-lung system facilitate the risk assessment of air-born particles such as asbestos fibers, ultrafine dusts, nanoplastics, and aerosols.

는 결과가 세포주 혹은 환자 시료를 통해 보고된 바 있 다(Chapman et al., 2005; Blázquez-Prieto et al., 2021). 석면섬 유에 노출되지 않은 II형 폐포 상피세포는 기계적 자극에 놓여 있을 때, 더 많은 양의 계면활성제를 분비하고, 발 달 단계에서 I형 폐포 상피세포로 분화하는 능력이 커지 는 것이 관찰되었다(Miroshnikova et al., 2017; Yang et al., 2020). 특히, 여러 형태로 폐 조직이 손상된 환자에게 인 공 호흡기(mechanical ventilator)를 통해 과도한 기계적 자 극이 주어졌을 때, 폐 섬유화 촉진에 따른 사망률이 증가 하는 것으로 알려졌다(Slutsky and Ranieri, 2013). 이는 석면 섬유에 노출된 환자의 폐 조직이 면역반응 및 폐 섬유화 가 진행되는 상황에서 인공 호흡기 처치가 이루어지면, 과도한 폐포의 기계적 팽창과 이완으로 인해 오히려 석면 섬유의 위해성이 더욱 증대될 수 있음을 시사한다. 따라 서, 이에 관한 향후 연구와 임상 현장에서 지속적인 모니 터링이 병행된다면 석면섬유 노출이 원인인 석면폐, 악성 중피종, 폐암환자에 대한 보다 적절한 치료 및 인공호흡 유도 폐 손상(ventilator-induced lung injury, VILI) 방지를 위 한 인공 호흡기의 사용 방안을 마련할 수 있을 것이다.

현재 주로 설치류 동물 모델에 대하여 시험 대기 안에 일정한 농도의 석면섬유를 노출시킨 후 호흡 시간에 따 른 폐 조직의 병리학적 변화를 분석함으로써 석면섬유의 폐 독성을 평가하고 있다. 하지만 전세계적 동물실험윤리 강화에 따른 3R (reduce, refine, replace) 정책에 따라 폐 독 성 동물 실험을 대처할 수 있는 실험법 모색이 필요한 실정이다. 뿐만 아니라 동물 모델의 폐와 인간의 폐 사이
의 해부학적/유전학적/생리학적 차이로 인하여 동물 모델 결과를 인간에게 적용하는데 있어 한계 및 불일치가 발 생하므로 좀더 직접적인 인간 폐 독성 평가 시스템 개발 이 필요하다. 이에 최근에 인간 폐포 조직의 형태와 기능 을 체외에서 재구성한 alveolus-on-a-chip이 개발되고 있다 (Huh et al., 2010; Roshanzadeh et al., 2020; Shrestha et al., 2020). 생리학과 미세유체공학(microfluidics)의 융합을 통 해 구축된 alveolus-on-a-chip은 인간의 폐포의 해부학적 구조, 기계적 자극, 그리고 생리학/면역학적 기능을 모사 할 수 있다. 이를 이용하여 석면섬유를 비롯한 초미세입 자, 이를테면 초미세먼지, 나노플라스틱, 에어로졸 형태 공기 부유 물질에 대한 폐포 독성 연구를 시도한다면 기 존의 동물 실험 기반의 독성 연구의 한계를 보완해 나갈 수 있을 것이다. 또한 단기 혹은 장기 석면섬유 노출에 따른 조직의 변화를 실시간 이미징과 다양한 생화학적 평가를 가능하게 함으로써 호홉기도의 폐 섬유화 과정과 관련된 분자생물학적 기전이 좀더 명확하게 규명될 것이 다. 가까운 미래에 폐의 해부학적 구성체계(기관 > 기관 지 > 소기관지 > 폐포)에 해당하는 세포를 사용하여 3D cell printing과 미세유체공학을 접목시켜 "mini-lung"이 체 외에서 구축될 것으로 기대된다(Fig. 5). 이를 통해 석면섬 유가 폐포 뿐만 아니라 다른 호흡 조직에 미치는 위해성 까지 파악할 수 있고, 폐 섬유화를 저해할 수 있는 약물 탐색(drug screening)과 정밀치료(precision therapy) 개발에 새로운 접근법으로 활용 가능해질 것으로 기대한다. 


\section{결 론}

본 총설은 석면섬유의 물리화학적 성질을 설명하고 석 면섬유가 폐포 세포에 미치는 독성을 분자생물학적 관점 에서 기술하였다. 인체 호흡기도에 도달한 석면섬유에 의 한 활성산소종과 활성질소종은 폐포를 구성하는 세포를 손상시킬 뿐 아니라 폐포 조직 내 면역세포들을 지속적으 로 활성화시킴으로써 최종적으로 폐 섬유화를 초래한다. 또한 석면섬유에 노출된 폐포 세포들이 유전체 손상을 완벽히 복구하지 못하여 악성 종양으로 진행될 수 있다. 석면섬유를 포함한 석면 제품들은 그 위해성이 밝혀 지기까지 지속적으로 사용되었고 현재 우리나라에서 석 면건축물을 해체하는 작업이 진행되고 있어 석면 노출에 의한 피해의 위험성은 여전히 남아있다. 2007년 국내에 서 석면 제품 사용이 금지되었지만 석면섬유로 인해 발 생하는 폐 섬유화는 30 40년의 잠복기를 통해 진행되기 때문에 과거에 석면섬유에 노출되었던 사람들에서 향후 10 20년 이내 석면폐, 악성 중피종, 폐암과 같은 질병이 발생할 가능성이 높다. 이에 본 총설을 통해 석면섬유의 호흡기도에 대한 독성 기전을 이해함으로써 석면 노출에 대한 예방 및 피해자 진단 및 치료 방안을 마련할 수 있 을 것이다. 석면 제품의 전면 사용 금지와 석면 노출에 대한 규제가 시행되고 있어, 석면섬유에 의한 호흡기 건 강 위협은 다행히 통제되고 있다고 볼 수 있다. 하지만 최근 대기 중 초미세먼지, 독성 물질이 함유된 에어로졸, 공기 매개 바이러스(airborne virus)와 같은 요인들이 국민 들의 호흡기 건강이 위협하고 있는 실정이다. 이에 향후 연구에서 체외에서 인체 호흡기의 기능과 구조를 모사한 alveolus-on-a-chip 혹은 mini-lung 시스템을 활용하여 석면 섬유를 비롯한 여러 요인에 의한 독성 연구가 수행될 것 으로 예측된다. 이를 통해 현재까지 명확하게 밝혀지지 않은 호흡기 조직의 환경 요인에 대한 반응에 있어 보다 명확한 기전 및 시공간적 인과관계를 밝혀낼 수 있으리 라 전망한다.

\section{ACKNOWLEDGEMENT}

This work was supported by Chonnam National University (Grant number: 2020-3829) and the National Research Foundation of Korea (NRF) grant funded by the Korea government (MSIT) (Grant number: 2021R1F1A1049470).

\section{CONFLICT OF INTEREST}

The author has declared no conflict of interest.

\section{REFERENCES}

Barlow CA, Grespin M, Best EA. Asbestos fiber length and its relation to disease risk. Inhal Toxicol. 2017. 29: 541-554.

Blázquez-Prieto J, Huidobro C, López-Alonso I, et al. Activation of p21 limits acute lung injury and induces early senescence after acid aspiration and mechanical ventilation. Transl Res. 2021. 233: 104-116.

Chapman KE, Sinclair SE, Zhuang D, et al. Cyclic mechanical strain increases reactive oxygen species production in pulmonary epithelial cells. Am J Physiol Lung Cell Mol Physiol. 2005. 289: L834-L841

Choi JK, Paek DM, Paik NW. The Production, the Use, the Number of Workers and Exposure Levels of Asbestos in Korea. Korean Ind Hyg Assoc J. 1998. 8: 242-253.

Duffield JS, Forbes SJ, Constandinou CM, et al. Selective depletion of macrophages reveals distinct, opposing roles during liver injury and repair. J Clin Invest. 2005. 115: 56-65.

Fajgenbaum DC, June CH. Cytokine storm. N Engl J Med. 2020. 383: $2255-2273$

Fontecave M, Jaouen M, Mansuy D, et al. Microsomal lipid peroxidation and oxy-radicals formation are induced by insoluble iron-containing minerals. Biochem Biophys Res Commun 1990. 173: $912-918$

Gang DM. Health Effects of Environmental Asbestos Exposure. J Environ Health Sci. 2009. 35: 71-77.

Ghio AJ, Taylor DE, Stonehuerner JG, Piantadosi CA, Crumbliss AL. The release of iron from different asbestos structures by hydrogen peroxide with concomitant $\mathrm{O}_{2}$ generation. Biometals. 1998. 11: 41-47.

Hanley GD, Kess S, Stevens YW, et al. Toxicological profile for asbestos. 2001. Dept. of Health and Human Services, Public Health Service, Agency for Toxic Substances and Disease Registry. Atlanta, United States.

Huang SX, Partridge MA, Ghandhi SA, Davidson MM, Amundson SA, Hei TK. Mitochondria-derived reactive intermediate species mediate asbestos-induced genotoxicity and oxidative stress-responsive signaling pathways. Environ Health Perspect. 2012. 120: 840-847.

Huh D, Matthews BD, Mammoto A, et al. Reconstituting OrganLevel Lung Functions on a Chip, Science. 2010. 328: 1662 
1668.

IARC Working Group on the Evaluation of Carcinogenic Risks to Humans. Arsenic, Metals, Fibers and Dusts. 2012. Vol 100C, pp. 219-294. International Agency for Research on Cancer. Lyon, France.

Ishida T, Fujihara N, Nishimura T, et al. Live-cell imaging of macrophage phagocytosis of asbestos fibers under fluorescence microscopy. Genes Environ. 2019. 41: 1-11.

Jablonski RP, Kim SJ, Cheresh P, et al. SIRT3 deficiency promotes lung fibrosis by augmenting alveolar epithelial cell mitochondrial DNA damage and apoptosis. FASEB J. 2017. 31: 2520-2532.

Jiang L, Nagai H, Ohara H, et al. Characteristics and modifying factors of asbestos-induced oxidative DNA damage. Cancer Sci. 2008. 99: 2142-2151.

Kim HW, Park GY, Han JG, et al. Releasing of asbestos fibers from the weathered asbestos cement slate roofing. J Korean Soc Occup Environ Hyg. 2010. 20: 88-93.

Kim YS. Regulations and status of asbestos management in foreign countries. Air Cleaning Technol. 2009. 22: 11-20.

Koerten HK, Bruijn de JD, Daems WT. The formation of asbestos bodies by mouse peritoneal macrophages: An in vitro study. Am J Pathol. 1990. 137: 121-134.

Ko S, Ko J, Oh M, et al. A Study on the Development of Asbestos Victims and the Estimation of Fund Requirements. 2020. pp. 75-95. Korea Institute for Health and Social Affairs. Sejong, Korea.

Kwan YS, Kim KS, Kim SO, et al. Respirology. 2010. pp. 115117. Chonnam National University Press, Gwangju, Korea.

Macnab G, Harington JS. Haemolytic activity of asbestos and other mineral dusts. Nature. 1967. 214: 522-523.

Miroshnikova YA, Nava MM, Wickström SA. Emerging roles of mechanical forces in chromatin regulation. J Cell Sci. 2017. 130: 2243-2250.

Rappolee DA, Mark D, Banda MJ, Werb Z. Wound macrophages express TGF-alpha and other growth factors in vivo: analysis by mRNA phenotyping. Science. 1988. 241: 708-712.

Rosenthal GJ, Simeonova P, Corsini E. Asbestos toxicity: an immunologic perspective. Rev Environ Health. 1999. 14: 1120.

Roshanzadeh A, Park S, Ganjbakhsh ES, et al. Surface Chargedependent Cytotoxicity of Plastic Nanoparticles in Alveolar Cells under Cyclic Stretches. Nano Lett. 2020. 20: 7168-7176.
Schinwald A, Donaldson K. Use of back-scatter electron signals to visualize cell/nanowires interactions in vitro and in vivo; frustrated phagocytosis of long fibers in macrophages and compartmentalisation in mesothelial cells in vivo. Part Fiber Toxicol. 2012. 9: 1-14.

Seaton A. Non-occupational exposure to mineral fibres. J Epidemiol Community Health. 1989. 43: 404.

Shrestha J, Bazaz SR, Aboulkheyr Es H, et al. Lung-on-a-chip: the future of respiratory disease models and pharmacological studies. Crit Rev Biotechnol. 2020. 40: 213-230.

Shukla A, Ramos-Nino M, Mossman B. Cell signaling and transcription factor activation by asbestos in lung injury and disease. Int J Biochem Cell Biol. 2003. 35: 1198-1209.

Shukla A, Jung M, Stern M, et al. Asbestos induces mitochondrial DNA damage and dysfunction linked to the development of apoptosis. Am J Physiol Lung Cell Mol Physiol. 2003. 285: 1018-1025.

Slutsky AS, Ranieri VM. Ventilator-induced lung injury. N Engl J Med. 2013. 369: 2126-2136.

Solbes E, Harper RW. Biological responses to asbestos inhalation and pathogenesis of asbestos-related benign and malignant disease. J Investig Med. 2018. 66: 721-727.

Sun J, Druhan LJ, Zweier JL. Reactive oxygen and nitrogen species regulate inducible nitric oxide synthase function shifting the balance of nitric oxide and superoxide production. Arch Biochem Biophys. 2010. 494: 130-137.

Toyokuni S. Mechanisms of asbestos-induced carcinogenesis. Nagoya J Med Sci. 2009. 71: 1-10.

Wynn TA, Chawla A, Pollard JW. Macrophage biology in development, homeostasis and disease. Nature. 2013. 496: 445-455.

Wynn TA, Ramalingam TR. Mechanisms of fibrosis: therapeutic translation for fibrotic disease. Nat Med. 2012. 18: 1028-1040.

Wynn TA, Vannella KM. Macrophages in Tissue Repair, Regeneration, and Fibrosis. Immunity. 2016. 44: 450-462.

Yang J, Pan X, Wang L, Yu G. Alveolar cells under mechanical stressed niche: critical contributors to pulmonary fibrosis. Mol Med. 2020. 26: 95.

https://doi.org/10.15616/BSL.2021.27.3.111

Cite this article as: Jung JW, Kim ES. Pulmonary Fibrosis caused by Asbestos Fibers in the Respiratory Airway. Biomedical Science Letters. 2021. 27: 111-120. 